\title{
Entrepreneurial visions of the self: language teaching and learning under neoliberal conditions
}

\author{
Martina Zimmermann \\ University of Teacher Education Lucerne \\ Sebastian Muth \\ Lancaster University
}

In this special issue, we bring together empirical research that takes a critical perspective on the relationship between language learning and individual aspirations for future success. In doing so we aim to initiate a debate on how neoliberal ideology and mode of governance permeate language learning as part of a wider neoliberal project that postulates the ideal of the competitive and self-responsible language learner. The four contributions illustrate how neoliberal desires about entrepreneurial selves play out differently within different social, political, or linguistic contexts. They do not only address different languages individuals supposedly need to teach or acquire for a successful future within a specific context, but also concentrate on the discourses and social relations shaping these entrepreneurial aspirations. Ranging from vocational training in Japan, early education in Singapore, healthcare tourism in India, to higher education in Switzerland, the contributions all illustrate the role of language as part of the struggle to improve either oneself or others. While the research sites illustrate that investments in language are simultaneously promising and risky and as such dependent on local and global linguistic markets, they equally highlight underlying language ideologies and reveal wider structures of inequality that are firmly embedded in local, national and global contexts.

Keywords: language teaching, language learning, education, commodification of language, neoliberalism, future, ethnography

Recently, one of the two authors got a telephone call from a radio station requesting an interview to be broadcasted on the "European Day of Languages" (September 26). The journalist left a voice message, outlining his request for a 5-minute interview about which languages one should learn in order to shine in the future. The interview never took place. Upon calling him back, he had already spoken to a different expert. Nevertheless, the question of what was meant by "shining in the future" was intriguing. When asked, the journalist mentioned keywords such as "success" and "career".

We, the two authors, thereupon had a discussion on what our answers would have been like, after all we are (socio-)linguists and not career advisers. We might perhaps have cautioned the journalist and highlighted that holding the individual responsible to become more competitive through the strategic acquisition of language is in itself a notion prone to generalization and, as such, highly dependent on individual preferences and interests. More likely though, we might have said that making predictions like this are not that easy based on what our own impressions as sociolinguists suggest.

Others are further ahead. Search engines such as Google offer suggestions about the "right", most profitable, most commodifiable and most sought-after language and as such are far less hesitant in coming up with recommendations. In fact, several websites specialize in linking languages with imagined futures. Gofluent.com, for instance, in 2018 aimed to identify specific linguistic markets and the 
value of language learning, concluding that English, Portuguese, Chinese, Spanish, German, French, and Italian are the most useful to learn. Each of these recommendations was accompanied by a short description including the number of speakers as well as some macro-economic commentary.

These observations tie in with overall aim of this special issue that aims to investigate language learning as part of a wider neoliberal project that postulates the ideal of the compettive and self-responsible language learner. Within this context we understand neoliberalism as a cultural order and a norm that is not only characterized by rising social inequality but also by a normalization of competition and a foregrounding of the self-responsible, adaptive and enterprising self (Dardot and Laval 2014; Gershon 2016; Harvey 2005; Urla 2019). The image of being competitive and ahead of everyone else also manifests itself through language and in particular in an understanding of communicative resources as skills that can be acquired, cultivated and employed. This understanding of language becomes a central instrument in gaining professional recognition, in securing or maintaining employment, in accessing local and transnational networks or in becoming mobile, flexible and adaptive citizens (Heller 2003; Park 2011; Urciuoli 2008; Urla 2019). Alongside this notion of strategic language acquisition within a neoliberal economic order, the ability to make informed choices can give a competitive edge in times of economic uncertainty. Indeed, education is a domain where anticipations of the future become particularly visible and tied in with the neoliberal logics of economic expansion and distinction, articulating and stylizing ideal speakers who will remain competitive on the labour market and facilitate future economic growth (Holborow 2015; Martin Rojo 2016; Piller and Cho 2013; Urciuoli 2008). Individuals themselves now share a responsibility for their economic and social progress with particular forms of bi- or multilingualism promising individual success through monetary gain (Duchêne and Heller 2012; Flores 2013; Gershon 2011; Heller 2003; Urciuoli 2008). In line with neoliberal logics, making the "right" and "appropriate" choices and the ability to capitalize on the imagined future value of an acquired communicative or cultural competence remains dependent on fluctuating linguistic markets and wider political-economic conditions (Gershon 2011: 540; O’Malley 1996). It is precisely this aspect that deserves further attention and that foregrounds particular conditions and rationales that prompt education systems as well as individuals to enter a process of continuously re-crafting themselves towards an end goal of "improvement", the former by adapting their curricula and the latter by seeking to become flexible entrepreneurs, competitors and consumers (Urciuoli 2015: 116; Ward 2012; Zimmermann and Flubacher 2017).

Thus, in this special issue that we argue for an understanding of "future" as a metaphor that describes the relationship between neoliberal ideology and language learning. Within this perspective, learning a language and cultivating one's language skills becomes part of an individual's responsibility. Moreover, language emerges as a strategic tool and as an instrument to advance careers, to access professional networks, to expand markets and, ultimately, to make a living. First, examining discourses about language learning sheds light on the education system and the status currently attributed to certain languages. Second, it exposes the ways in which individuals make sense of discourses linking language 
skills to both competitiveness and distinction. Anticipations of "promising" linguistic markets that ensure convertibility are informed by projections of economic potential for instance through market deregulation and liberalization as much as they are firmly embedded within language ideologies of the nation state and as expressions of (post)colonial structures of inequality. On the one hand, this is closely tied in with the notion of opportunity where language is regarded as a distinct skill that sets the speaker ahead of everyone else by exploiting a niche and by mastering a language only a few know. On the other hand, language learners invest in languages of wider communication with large numbers of speakers and of seemingly unlimited potentiality (Park 2011).

It is within this context that we ask how neoliberal ideology and modes of governance permeate language learning as part of a wider neoliberal project that postulates the ideal of the competitive and self-responsible language learner? How are visions of the entrepreneurial future produced, articulated and promoted? And what are the consequences of these visions for mono-, bi-, or multilingual speakers incompatible with uniform articulations of future selves? With these questions in mind, this special issue aims to critically investigate visions of the entrepreneurial future in the promotion of language teaching and learning in a range of linguistic, cultural, geographical, and educational contexts. Bringing together four data-driven contributions that take an intrinsically critical perspective on the relationship between language learning and individual aspirations of future success, we wish to reflect on the ways in which the political economy of capitalism in its current form engages in the reproduction of language ideologies through the articulation of specific pathways in language learning.

Centred on language learning and teaching, the four case studies focus on how neoliberal anticipations about entrepreneurial selves play out differently within various social, political, or linguistic contexts, ranging from vocational training in Japan, early education in Singapore, healthcare tourism in India, to higher education in Switzerland. They do not only investigate different languages individuals supposedly need to teach or acquire for a successful future within a specific context, but also address the discourses and social relations shaping these entrepreneurial aspirations and expectations. By scrutinizing these visions of professional success through language and the expectations these images create among individuals and institutions alike, the four contributions offer a deeper understanding of the role of language as part of the neoliberal restructuring of global economic, political and cultural relations. The contributions are all informed by ethnographic and/or discourse-analytical approaches. While the different research sites illustrate that investments in language are both promising and risky and as such dependent on local and global linguistic markets, equally they highlight underlying language ideologies and reveal wider structures of inequality that are firmly embedded in local, national and global contexts.

How is learning languages seen, and in what ways it is connected to expectations for an imagined future? Focusing on the experience of South Korean early English education (yeongeo jogi gyoyuk), Sohee Bae and Joseph Sung-Yul Park show how Singapore-based Korean early study abroad (jogi yuhak) families regard English as a crucial resource in order to prepare their children for a future as employable, competitive and mobile subjects. Concentrating on the Swiss higher education system, 
Martina Zimmermann illustrates how language competences serve as a promotional argument for students and institutions alike, reaching an almost incontestable status in terms of prophesies of the multilingual and thus marketable self. Reflecting upon health mobility in India, Sebastian Muth and Neelakshi Suryanarayan trace the trajectories of former students of Russian and thereby demonstrate their future aspirations as language learners and entrepreneurs. By doing so, they shed light on how these language learners aim to capitalize on language skills and respond to changing conditions and patient movements within the structures, constraints and uncertainties of the linguistic market. Finally, Ruriko Otomo explores the trajectories of healthcare workers from Indonesia and the Philippines in Japan who take part in a bilateral program established between Japan and a number of Southeast Asian countries to address a labour shortage in the Japanese care industry, and illustrates how learning Japanese is discursively constructed as a way to become employable. Within these different yet interrelated contexts, all four case studies highlight, how languages are reimagined as instrumental in building and securing future careers.

Besides this focus on future orientation, each paper also considers economic aspirations, imagined futures and the neoliberal economy as interrelated. That is, the papers see both discourses and individual choices as embedded in historical structures and as narratives of the nation state, as well as being aware that they contribute to fundamental social difference and take part in the reproduction of social inequality. In that respect, Bae and Park offer insights into the ways English continues to uphold the status as a hegemonic language within East and Southeast Asia which it gained during the aftermath of the Asian financial crisis in the late 1990s. Zimmermann illustrates similar hierarchies, where the desire of Italianspeaking university students to learn German affords a historical perspective on both Swiss multilingualism and the local linguistic market that ascribes exceptional value to German. Similar beliefs about language are also shaped in the Indian medical tourism industry, where Muth and Suryanarayan illustrate the ways English continues to mirror social and professional hierarchies even within an otherwise multilingual service industry. Lastly, Otomo shows how Japanese migration policy is shaped by an acute labour shortage that has resulted in the influx of care workers for whom learning Japanese is the only opportunity to reach (limited) professional and social recognition within a largely monolingual and monoethnic society.

With these contributions we thus aim to add to a growing body of literature that addresses the nexus between neoliberalism and education, and in particular contribute to a better understanding of language learning as neoliberal practice and as an expression of entrepreneurial agency (Flubacher and Del Percio 2017; Martin Rojo 2018; Muth and Del Percio 2018). At the same time, this special issue aims to highlight how individual choices in language learning are informed by speculation about language value within potentially volatile linguistic markets as much as they are part of language ideologies firmly embedded in national and transnational contexts. This, in turn enables us to illustrate the consequences of language learning as a form of neoliberal governance that declares self-improvement and the acquisition of distinctive and marketable skills as individual responsibilities (Flores 2013; Urla 
2019). It is through this lens that we can challenge celebratory discourses of multilingualism, investigate how these intersect with the political economy of language, and seek a better understanding of the ways, language learning is intertwined with both economic opportunity and larger structures of social inequality.

\section{References}

Dardot, Pierre \& Christian Laval. 2014. The new way of the world: On neoliberal society. London/Brooklyn: Verso Books.

Duchêne, Alexandre. 2016. Investissement langagier et économie politique. Language et Societé (157)3. 73-96.

Duchêne, Alexandre \& Monica Heller (eds.). 2012. Language in Late Capitalism: Pride and Profit. New York: Routledge.

Flores, Nelson. 2013. The unexamined relationship between neoliberalism and plurilingualism: A cautionary tale. TESOL Quarterly 47(3). 500-520.

Flubacher, Mi-Cha \& Alfonso Del Percio. 2017. Language, Education and Neoliberalism. Critical Studies in Sociolinguistics. Bristol: Multilingual Matters.

Gershon, Ilana. 2011. Neoliberal agency. Current Anthropology 52(4). 537-555.

Gershon, Ilana. 2016. "I'm not a businessman, I'm a business, man". Typing the neoliberal self into a branded existence. Journal of Ethnographic Theory 6(3). 223-246.

Harvey, David. 2005. A Brief History of Neoliberalism. Oxford: Oxford University Press.

Heller, Monica. 2003. Globalization, the new economy, and the commodification of language and identity. Journal of Sociolinguistics 7. 473-492.

Holborow, Marnie. 2015. Language and neoliberalism. London: Routledge.

Martin Rojo, Luisa. 2016. Language and power. In Ofelia García, Nelson Flores \& Massimiliano Spotti (eds.), The Oxford handbook of language and society, 77-102. Oxford: Oxford University Press.

Martin Rojo, Luisa. 2018. Neoliberalism and Linguistic Governmentality. In James W. Tollefson \& Miguel Pérez-Milans (eds.), Handbook of language policy and planning, 544-567. Oxford: Oxford University Press.

Muth, Sebastian \& Alfonso Del Percio. 2018. Policing for commodification: turning communicative resources into commodities. Special Issue. Language Policy 17(2).

O’Malley, Pat. 1996. Risk and responsibility. In Andrew Barry, Thomas Osbourne \& Nikolas Rose (eds.), Foucault and political reason: liberalism, neo-liberalism and rationalities of government, 189-208. Chicago: University of Chicago Press.

Park, Joseph Sung-Yul. 2011. The promise of English: linguistic capital and the neoliberal worker in the South Korean job market. International Journal of Bilingual Education and Bilingualism 14(4). 443-455.

Piller, Ingrid \& Jinhyun Cho. 2013. Neoliberalism as language policy. Language in Society 42. 23-44.

The Most Useful Languages to Learn in 2019. Gofluent. https://www.gofluent.com/blog/most-usefullanguages-2019/ (accessed 20.07.2019).

Urciuoli, Bonnie. 2008. Skills and selves in the new work place. American Ethnologist 35(2). 211-228.

Urciuoli, Bonnie. 2015. The metaculture of law school admissions: A commentary on Lazarus-Black and Globokar. Indiana Journal of Global Legal Studies 22(1). 113-119.

Urla, Jacqueline. 2019. Governmentality and language. Annual Review of Anthropology 48(1). 261278.

Ward, Steven C. 2012. Neoliberalism and the Global Restructuring of Knowledge and Education. New York: Routledge.

Zimmermann, Martina \& Mi-Cha Flubacher. 2017. Win-Win?! Language regulation for competitiveness in a university context. In Mi-Cha. Flubacher \& Alfonso Del Percio (eds.), Language, Education and Neoliberalism Critical Studies in Sociolinguistics, 204-228. Bristol: Multilingual Matters. 